\title{
Agrometeorological Indices in Relation to Phenology and Yield of Rice Genotype (Oryza sativa L.) under Upper Brahmaputra Valley Zone of Assam, India
}

\author{
Kuldip Medhi ${ }^{{ }^{*}}$, Prasanta Neog ${ }^{2}$, Bondita Goswami ${ }^{3}$, Rajib Lochan Deka ${ }^{3}$ \\ and Rofiul Hussain ${ }^{3}$ \\ ${ }^{1}$ Regional Agricultural Research Station, Assam Agricultural University, \\ Gossaigaon-783360, India \\ ${ }^{2}$ Department of Agrometeorology, B.N. College of agriculture, Biswanath \\ Chariali-784176, India \\ ${ }^{3}$ Department of Agrometeorology, Assam Agricultural University, Jorhat-785013, India \\ *Corresponding author
}

\section{Keywords}

Cultivars, GDD, HTU, HUE, PTI, Phenological stages, rice

Article Info

Accepted:

12 May 2019

Available Online:

10 June 2019

\section{A B S T R A C T}

A field experiment was carried out during kharif, 2015 in the Instructional cum Research (ICR) Farm of Assam Agricultural University, Jorhat, Assam (at a latitude of $26^{\circ} 47^{\prime} \mathrm{N}$, longitude of $94^{\circ} 12^{\prime} \mathrm{E}$ and altitude of $87 \mathrm{~m}$ above mean sea level) with two cultivars of rice $v i z$. Luit and TTB-404 grown in different micro climatic regimes created by manipulating the sowing as well as transplanting dates. Both the cultivars were sown on four different dates at fifteen days interval starting from 26 June, 2015 upto 10 August, 2015 following field layout factorial RBD. Agroclimatic indices viz., Growing Degree Day (GDD), Heliothermal Unit (HTU), Phenothermal Index (PTI) and Heat Use Efficiency (HUE) for attaining different phenological stages in both the cultivars were studied. Accumulated GDD at physiological maturity in different dates of sowing were relatively higher in TTB404 which varied from $2034.3^{\circ} \mathrm{C}$ to $2470.9^{\circ} \mathrm{C}$, while in Luit it varied from $1685.4^{\circ} \mathrm{C}$ to $1928.1^{\circ} \mathrm{C}$. With delay in sowing date, GDD accumulation till physiological maturity decreases in both the cultivars. Comparatively, in $c v$. Luit higher grain yield was recorded in the crop sown on D2 (11 July) and D3 (26 July), while in TTB-404 it was recorded in D2 (11 July) and yield in both the cultivars declines gradually with crop transplanted beyond first fortnight of August. Furthermore, the grain yield of both the cultivars was significantly correlated with accumulated GDD and HTU during transplanting to maximum tillering stage with correlation coefficients (r) $0.92 * *$ and $0.72 *$ respectively.

\section{Introduction}

The rice crop Oryza sativa; can be classified as a heat loving hydrophytes, known for its wide popularity as a staple food of more than half of the world population. Rice is a core cash crop and considered as a staple food in many Asian countries (Rao et al., 2007; Kumar and Ladha, 2011; Matloob et al., 2015). Swaminathan (1999) revealed that rice is cultivated all over the world in highly diverse condition from $50^{\circ} \mathrm{N}$ to $35^{\circ} \mathrm{S}$. The south Asian country India is the largest rice growing country under varying climatic 
conditions within $8^{0} \mathrm{~N}$ to $34^{0} \mathrm{~N}$ latitude, and it accounts for more than $40 \%$ of food grain production, providing direct employment to $70 \%$ people in rural areas (Shamim et al., 2013). Despite of several technological advancements in the field of agriculture, weather is the leading factor that determines the success or failure of agricultural enterprise. Like other crops, growth, development and yield of rice crop are greatly influenced by prevailing weather condition during the growth period of the crop. Various environmental factors influencing crop growth are interception of photosynthetically active radiation, air and leaf temperatures, relative humidity, prevailing wind speed, $\mathrm{CO}_{2}$ concentration and soil moisture availability etc. (Kaur and Dhaliwal, 2014), however the role of temperature is very much critical among several weather elements.

Most of the latest high yielding rice varieties are thermosensitive and their growth duration and development phases are greatly influenced by ambient temperature (Mavi, 1994). A minimum of $10^{\circ} \mathrm{C}$ temperature is required for sprouting, while the optimum temperature required for flowering and for grain formation ranges from $22^{\circ} \mathrm{C}$ to $23^{\circ} \mathrm{C}$ and $20^{\circ} \mathrm{C}$ to $21^{\circ} \mathrm{C}$, respectively (Thomas, 1957). Average temperature required throughout the life period of the rice crop ranges from $21^{\circ} \mathrm{C}$ to $37^{\circ} \mathrm{C}$. At the time of tillering, the crop requires high temperature for growth. However, the temperature requirement in reproductive stage is in the range of $26.5^{\circ} \mathrm{C}$ to $29.5^{\circ} \mathrm{C}$, whereas temperature at the time of ripening should be in between $20^{\circ} \mathrm{C}$ to $25^{\circ} \mathrm{C}$.Singh (2000) detected that low light coupled with high temperature $\left(38^{\circ} \mathrm{C}\right)$ and humidity (94\%) induced complete spikelet sterility, enhanced foliage growth and impaired the biological yield. Similarly, Alvarado (2002) reported that average temperature under $20^{\circ} \mathrm{C}$ for 5 days during flowering increased the probability of obtaining spikelet sterility greater than 10-12 per cent. Moreover, the average temperature required throughout the life period of the rice crop ranges from $21^{\circ} \mathrm{C}$ to $37^{\circ} \mathrm{C}$ (De Datta, 1981).

Plants have a definite temperature requirement to complete different phenophases and thermal accumulation study helps in estimating the phase specific heat unit requirement of the crop. The occurrence of different phenological events during crop growth period in relation to temperature can be estimated by using accumulated heat units or growing degree-days (GDD) (Gouri et al., 2005).

The heat unit concept helps in explaining direct and linear relationship between growth and temperature for the assessment of yield potential of a crop in different weather conditions (Kumar et al., 2014). Moreover, the heat unit system was also adopted for determining the maturity dates in different crops (Bierhuizen, 1973). However, the optimum utilization of these thermal units can also vary among different rice cultivars (Sandhu et al., 2013).

The most commonly used thermal indices by several researchers for estimating plant growth and development are Growing Degree Days (GDD), Phenothermal Index (PTI), Heliothermal Units (HTU) and Heat Use Efficiency (HUE) (Qadir et al., 2006; Shamim et al., 2013; Abhilash et al., 2017; Chaudhari et al., 2019; Kaur and Dhaliwal, 2014).In addition, HTU are also considered here; since phasic development and yield of crop are influenced by both temperature and photoperiod. In the present investigation, the effect of ambient temperature on phenological development and thermal accumulation of two rice cultivar exposed to different microclimates by manipulating their planting dates was studied. 


\section{Materials and Methods}

The field experiments was set during kharif, 2015 in the Instructional cum Research (ICR) farm of Assam Agricultural University, Jorhat situated at the latitude of $26^{\circ} 47^{\prime}$ North, longitude $94^{\circ} 12^{\prime}$ 'East and altitude $87 \mathrm{~m}$ above mean sea level. Jorhat is a sub-tropical station with hot and humid summers and cold and dry winters. The mean annual rainfall is 1900 $\mathrm{mm}$, of which 62.6 per cent is receiving during southwest monsoon season from July to September. During post monsoon (October - November), pre-monsoon (March -May) and winter season (December - February) the station receives 7.5, 26.2 and 3.7 per cent of annual rainfall, respectively. The rainy season starts in the mid of March and quantum of rainfall as well as number of rainy days increases gradually and reaches maximum in the month of July and then decline to minimum during December. Monthly morning relative humidity of the station always remains above 85 per cent whereas monthly evening relative humidity varies from 61 to 76 per cent throughout the year. The monthly average maximum and minimum temperatures varies from $22.6^{\circ} \mathrm{C}$ to $32.7^{\circ} \mathrm{Cand} 9.7^{\circ} \mathrm{C}$ to $25.2^{\circ} \mathrm{C}$, respectively. June, July and August are the hottest months with mean daily maximum temperature varying from $19.6^{\circ} \mathrm{C}$ to $37.6^{\circ} \mathrm{C}$; while January is the coldest month with mean daily minimum temperatures ranging from $5.0^{\circ} \mathrm{C}$ to $18.2^{\circ} \mathrm{C}$. The overall weather scenario of the experimental site during kharif, 2015 were presented in Figure 1 and 2.

The field experiment was laid out in factorial Randomized Block Design (RBD) (with three replications) with four dates of sowing at the interval of 15 days from 26 June to 10 August, 2015 with two cultivars viz., Luit and TTB-404. The cultivar Luit is a short duration i.e. 100-105 days variety whereas the TTB404 is a medium duration variety with average duration of 135 days. Twenty five days old seedlings were used in transplanting for both the cultivars at 21 July, 5 August, 20 August and 4 September during kharif, 2015. The crop was grown following recommended agronomic practices. The daily weather data were recorded in the Agro-meteorological observatory situated adjacent to the experimental plot.

The varieties are sown in nursery bed followed by transplanting to main field during the kharif, 2015. Under rainfed cropping system, transplanting of rice seedling is a major feature. Patel and Charugamba (1981) stated that transplanted rice is capable of yielding $30 \%$ more than the broadcasted rice. The other advantage of transplanting is effective utilization of rainy season and faster maturity of the rice crop particularly in rainfed lowland rice ecosystems since the crop partly passes some of its growth stage in nursery (Morris, 1980; Abeysiriwardena et al., 2005). Under the present investigation, the recorded phenological events areemergence, maximum tillering, 50\% flowering and physiological maturity. For better interpretation in estimation of overall thermal accumulation of the crop from sowing to physiological maturity, transplanting of seedlings from nursery to main field was considered as an event. However, transplanting is not a phenological stage. The phenological stages were recorded based on the frequent inspection of crop field.

The thermal indices are calculated using following formulae-

Growing Degree day (GDD): The thermal time is calculated from the following expression given by Kaur and Dhaliwal (2014).

$\mathrm{GDD}=\left[\left(\frac{\mathrm{T}_{\max }+\mathrm{T}_{\min }}{2}\right)-\mathrm{T}_{\text {base }}\right]{ }_{\left({ }^{\circ} \mathrm{C}\right)}$ 
Where, $\mathrm{T}_{\max }$ and $\mathrm{T}_{\min }$ represent daily maximum and minimum temperature and $\mathrm{T}_{\text {base }}$ is the base temperature of $10^{\circ} \mathrm{C}$ was used (Sandhu et al., 2013).

Heliothermal Unit (HTU): It is calculated using the following expression given by Chakravarty and Sastry (1983).

HTU $=$ GDD $\times$ Actual Bright Sunshine hours $\left({ }^{\circ} \mathrm{Chr}\right)$

Phenothermal Index (PTI): Chakravarty and Sastry (1983) and Kar (1996) earlier used this index in wheat and mustard crops respectively.

PTI = Degree days between any specified duration

Duration $\quad{ }^{\circ}$

C/day)

Heat Use Efficiency (HUE): In the present study, HUE for straw and grain yield after the harvesting of crop were calculated following Shamim et al., (2013), for which straw and grain yield and the GDD from sowing to maturity were used.

HUE

Yield (Grain or Straw yield)

Total degree day accumulation $\left(\mathrm{kg} / \mathrm{ha} /{ }^{\circ} \mathrm{C}\right)$

To study the association of different thermal indices with the crop yield, the simple correlation co-efficient (r) were calculated.

\section{Results and Discussion}

\section{Growing Degree Days (GDD)}

\section{Nursery stage}

The highest numbers of GDD were accumulated by 26 June sowing (21 July transplanting) followed by 11July, 26 July and 10 August sowing in both the cultivars during kharif, 2015 (Table 1). The value in Table 1 indicated that the total number of days taken by both the cultivar for sowing to emergence stage for first date of sowing (D1) were six days, five days for second (D2) and third date (D3) and again six days for fourth date (D4), with total GDD values for first, second, third and fourth date of sowing were $119.0^{\circ} \mathrm{C}, \quad 117.7^{\circ} \mathrm{C}, \quad 121.6^{\circ} \mathrm{C}$ and $115.5^{\circ} \mathrm{C}$ respectively. The higher values of GDD were recorded in D3 followed by D1, D2 and D4. During this period from sowing to emergence, the average of maximum and minimum temperature values were $29.8^{\circ} \mathrm{C}, 29.6^{\circ} \mathrm{C}$, $30.3^{\circ} \mathrm{C}$ and $29.3^{\circ} \mathrm{C}$ for D1, D2, D3 and D4 respectively. The heat unit accumulation during the nursery stage (from sowing to transplanting) for D1, D2, D3 and D4 were $498.0^{\circ} \mathrm{C}, \quad 484.9^{\circ} \mathrm{C}, \quad 479.4^{0} \mathrm{C}$ and $455.7^{\circ} \mathrm{C}$ respectively for both the cultivars.

\section{Transplanting to Maximum tillering stage}

It was observed that the total number of days in $c v$. Luit for transplanting to maximum tillering stage for first (21 July) and second (5 August) date of transplanting were 19 days, 18 days for third date (20 August) and 17 days for fourth date (4 September) of transplanting during kharif, 2015. The GDD accumulationin Luit cultivar during transplanting to maximum tillering stage for first, second, third and fourth date of transplanting were $358.1^{\circ} \mathrm{C}, 350.7^{\circ} \mathrm{C}, 317.3^{\circ} \mathrm{C}$ and $321.4^{\circ} \mathrm{C}$, respectively. In the same way, the total number of days in cv. TTB-404 for same stage for first and second date of transplanting were 48 days, 50 days for third date and 54 days for fourth date of transplanting and total GDD values for first, second, third and fourth date of transplanting were $922.8^{0} \mathrm{C}, 903.6^{\circ} \mathrm{C}, 934.1^{0} \mathrm{C}$ and $958.9^{\circ} \mathrm{C}$, respectively. It was evident from Table 1 that for cv. Luit, highest value of GDD were recorded under first (21July) date of 
transplanting and lowest under the third date (20 August). For Luit, the average of maximum and minimum temperature values during transplanting to maximum tillering stage were $28.8^{\circ} \mathrm{C}, 28.5^{\circ} \mathrm{C}, 27.6^{\circ} \mathrm{C}$ and $28.9^{\circ} \mathrm{C}$ respectively. Thus it was evident that GDD decreases with the late transplanting for Luit cultivar. Similar types of findings were recorded by Kaur and Dhaliwal (2014).

In contrary, for cv. TTB-404 highest values of GDD were recorded in fourth (4 September) date of transplanting followed by third (20 August), first (21 July) and lowest in second (5 August) during transplanting to maximum tillering stage. During this period, the average of maximum and minimum temperature values for TTB-404 were $28.4^{\circ} \mathrm{C}, 28.4^{\circ} \mathrm{C}$, $28.3^{\circ} \mathrm{C}$ and $27.5^{\circ} \mathrm{C}$ for first, second, third and fourth date of transplanting. The thermal requirement was estimated maximum in TTB404 during this stage, as number of days required for reaching maximum tillering stage from transplanting is comparatively more than any other phenological stages considered in the present study. Thus it can be interpreted from the above result that total GDD to reach maximum tillering stage is positively related with the duration of growth stages. Similar types of findings were recorded by Mote et al., (2015).

\section{Maximum tillering to $50 \%$ flowering stage}

The number of days required to attain $50 \%$ flowering stage in Luit ranges from 34 to 36 days and 30 to 32 days in TTB-404. The Table 1 indicated that, higher values of GDD in Luit were recorded in D1 $\left(564.7^{\circ} \mathrm{C}\right)$ followed by D2 $\left(552.9^{\circ} \mathrm{C}\right), \mathrm{D} 3\left(544.8^{0} \mathrm{C}\right)$ and D4 $\left(520.6^{0} \mathrm{C}\right)$. Among other phenological stages in Luit, the maximum thermal accumulation was recorded during this period only (Table 1), as the number of days required to reach $50 \%$ flowering stage from maximum tillering stage was comparatively more.
During this period from maximum tillering to $50 \%$ flowering stage, the average temperature experienced by Luit cultivar were $28.2^{\circ} \mathrm{C}$, $28.4^{\circ} \mathrm{C}, 28.8^{\circ} \mathrm{C}$ and $27.4^{\circ} \mathrm{C}$ for D1, D2, D3 and D4 respectively. Similarly, the heat unit accumulations estimated for TTB-404 were $597.8^{\circ} \mathrm{C}$ (D1), $564.4^{\circ} \mathrm{C}$ (D2), $452.3^{\circ} \mathrm{C}$ (D3) and $374.6^{\circ} \mathrm{C}$ (D4). During this crop stage the $c v$. TTB-404 exposed to an average temperature of $28.8^{0} \mathrm{C}$ (D1), $27.2^{0} \mathrm{C}$ (D2), $24.7^{\circ} \mathrm{C}(\mathrm{D} 3)$ and $21.7^{\circ} \mathrm{C}(\mathrm{D} 4)$.

\section{$50 \%$ flowering to physiological maturity}

In case of grain development phase beginning from $50 \%$ flowering to physiological maturity, the higher thermal accumulation was recorded in $\mathrm{D} 1$ i.e. $507.3^{0} \mathrm{C}$ in Luitand $452.3^{\circ} \mathrm{C}$ in TTB-404. However, number of days required to attain physiological maturity from $50 \%$ flowering was recorded highest in D4 in both the cultivars (Table 1).

During this phase, the crop was exposed to an average temperature of $28.8{ }^{\circ} \mathrm{C}, 27.3^{\circ} \mathrm{C}$, $25.5^{\circ} \mathrm{C}$ and $22.9^{\circ} \mathrm{Cin}$ case of Luit and $24.9^{\circ} \mathrm{C}$, $22.3^{\circ} \mathrm{C}, 20.3^{\circ} \mathrm{C}$ and $17.2^{\circ} \mathrm{Cin}$ case of TTB404. The flowering period of TTB-404 sown during D3 and D4 exposed to a minimum temperature less than $15^{\circ} \mathrm{C}$, this significantly affects crop yield. Between the anthesis to physiological maturity period, GDD accumulation decreases with delay in transplanting. Similar types of observations were also recorded by Singh et al., (2012).

\section{Sowing to physiological maturity}

The accumulated GDD to reach physiological maturity during different sowing dates ranged between $1685.4^{\circ} \mathrm{C}$ to $1928.1^{\circ} \mathrm{C}$ and $2034.3^{\circ} \mathrm{C}$ to $2470.9^{\circ} \mathrm{C}$ for varieties Luit and TTB-404, respectively. In both the cultivar highest AGDD was recorded in first date of sowing (26 June) and lowest in fourth date of sowing (10 August) (Table 1). 
Fig.1 Mean weekly variation of maximum and minimum temperature and total weekly rainfall during crop growing period kharif, 2015

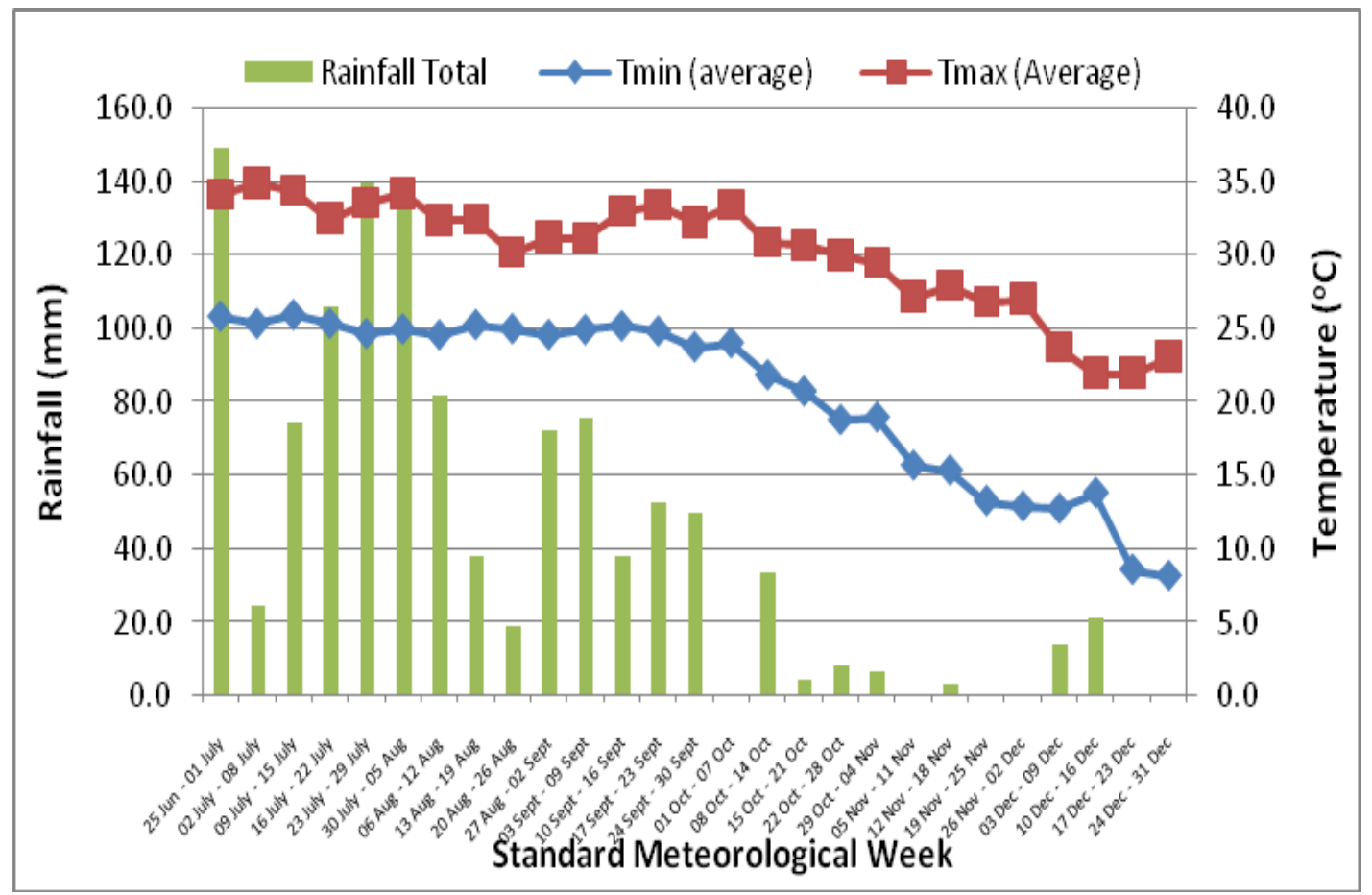

Fig.2 Mean weekly variation of sunshine hours during crop growing period kharif, 2015

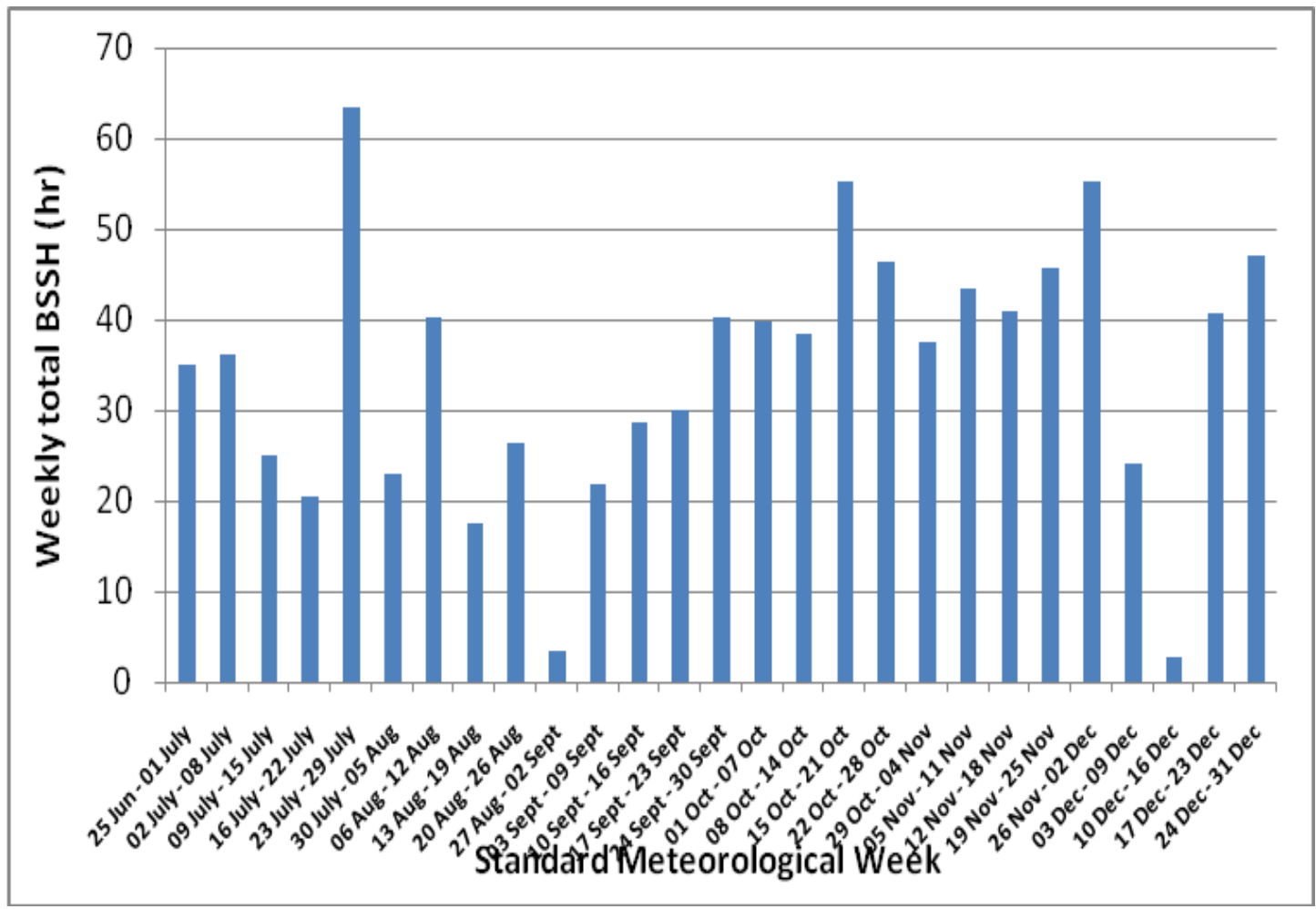


Table.1 Phenological duration and accumulated growing degree days $\left({ }^{\circ} \mathrm{C}\right)$ for rice varieties Luit \& TTB-404 under four different sowing dates during Kharif 2015

\begin{tabular}{|c|c|c|c|c|c|c|c|c|c|c|c|c|}
\hline \multirow[t]{2}{*}{$\begin{array}{c}\text { Date } \\
\text { Of } \\
\text { Sowing }\end{array}$} & \multicolumn{2}{|c|}{$\begin{array}{l}\text { Sowing to } \\
\text { emergence }\end{array}$} & \multicolumn{2}{|c|}{$\begin{array}{l}\text { Emergence to } \\
\text { transplanting }\end{array}$} & \multicolumn{2}{|c|}{$\begin{array}{c}\text { Transplanting } \\
\text { to } \\
\text { Maximum } \\
\text { Tillering }\end{array}$} & \multicolumn{2}{|c|}{$\begin{array}{c}\text { Maximum } \\
\text { Tillering To } \\
\text { 50\% flowering }\end{array}$} & \multicolumn{2}{|c|}{$\begin{array}{c}50 \% \text { flowering } \\
\text { to } \\
\text { Physiological } \\
\text { Maturity }\end{array}$} & \multicolumn{2}{|c|}{$\begin{array}{c}\text { Sowing to } \\
\text { Physiological } \\
\text { maturity }\end{array}$} \\
\hline & Days & GDD & Days & GDD & Days & GDD & Days & GDD & Days & GDD & Days & GDD \\
\hline \multicolumn{13}{|c|}{ Luit } \\
\hline D1- 26June, 2015 & 6 & 119.0 & 19 & 379.0 & 19 & 358.1 & 31 & 564.7 & 27 & 507.3 & 102 & 1928.1 \\
\hline D2- 11 July, 2015 & 5 & 117.7 & 20 & 367.2 & 19 & 350.7 & 30 & 552.9 & 27 & 467.1 & 101 & 1855.6 \\
\hline D3- 26 July, 2015 & 5 & 121.6 & 20 & 357.8 & 18 & 317.3 & 29 & 544.8 & 26 & 404.2 & 98 & 1745.7 \\
\hline $\begin{array}{c}\text { D4-10 August, } \\
2015\end{array}$ & 6 & 115.5 & 19 & 340.2 & 17 & 321.4 & 30 & 520.6 & 30 & 387.7 & 102 & 1685.4 \\
\hline Mean & 5.5 & 118.5 & 19.5 & 361.1 & 18.3 & 336.9 & 30.0 & 545.8 & 27.5 & 441.6 & 100.8 & 1803.7 \\
\hline \multicolumn{13}{|c|}{ TTB -404 } \\
\hline $\begin{array}{l}\text { D1- 26 June, } \\
2015\end{array}$ & 6 & 119.0 & 19 & 379.0 & 48 & 922.8 & 31 & 597.8 & 30 & 452.3 & 134 & 2470.9 \\
\hline D2- 11 July, 2015 & 5 & 117.7 & 20 & 367.2 & 48 & 903.6 & 32 & 564.4 & 31 & 390.2 & 136 & 2343.1 \\
\hline D3- 26 July, 2015 & 5 & 121.6 & 20 & 357.8 & 50 & 934.1 & 30 & 452.3 & 30 & 316.5 & 135 & 2182.3 \\
\hline $\begin{array}{l}\text { D4-10 August, } \\
2015\end{array}$ & 6 & 115.5 & 19 & 340.2 & 54 & 958.9 & 31 & 374.6 & 33 & 245.1 & 143 & 2034.3 \\
\hline Mean & 5.5 & 118.5 & 19.5 & 361.1 & $\mathbf{5 0 . 0}$ & 929.9 & 31.0 & 497.3 & 31.0 & 351.0 & 137.0 & 2257.7 \\
\hline
\end{tabular}

Table.2 Accumulated phenothermal index $\left({ }^{\circ} \mathrm{C} /\right.$ day $)$ in different phenological stages of Luit and TTB-404 under four different sowing dates during kharif, 2015

\begin{tabular}{|c|c|c|c|c|c|c|}
\hline Date Of Sowing & $\begin{array}{l}\text { Sowing to } \\
\text { emergence }\end{array}$ & $\begin{array}{l}\text { Emergence to } \\
\text { transplanting }\end{array}$ & $\begin{array}{l}\text { Transplantin } \\
\text { g to } \\
\text { Maximum } \\
\text { Tillering } \\
\end{array}$ & $\begin{array}{c}\text { Maximum } \\
\text { Tillering To } \\
50 \% \\
\text { flowering }\end{array}$ & $\begin{array}{c}50 \% \\
\text { flowering to } \\
\text { Physiological } \\
\text { Maturity }\end{array}$ & $\begin{array}{l}\text { Sowing to } \\
\text { Physiological } \\
\text { maturity }\end{array}$ \\
\hline \multicolumn{7}{|c|}{ Luit } \\
\hline D1- 26 June, 2015 & 19.8 & 19.9 & 18.8 & 18.2 & 18.8 & 18.9 \\
\hline D2- 11 July, 2015 & 23.5 & 18.4 & 18.5 & 18.4 & 17.3 & 18.4 \\
\hline D3- 26 July, 2015 & 24.3 & 17.9 & 17.6 & 18.8 & 15.5 & 17.8 \\
\hline $\begin{array}{c}\text { D4-10 August, } \\
2015\end{array}$ & 19.3 & 17.9 & 18.9 & 17.4 & 12.9 & 16.5 \\
\hline Mean & 21.7 & 18.5 & 18.5 & 18.2 & 16.1 & 17.9 \\
\hline \multicolumn{7}{|c|}{ TTB -404 } \\
\hline D1- 26 June, 2015 & 19.8 & 19.9 & 19.2 & 19.3 & 15.1 & 18.4 \\
\hline D2- 11 July, 2015 & 23.5 & 18.4 & 18.8 & 17.6 & 12.6 & 17.2 \\
\hline D3- 26 July, 2015 & 24.3 & 17.9 & 18.7 & 15.1 & 10.6 & 16.2 \\
\hline $\begin{array}{l}\text { D4-10 August, } \\
2015\end{array}$ & 19.3 & 17.9 & 17.8 & 12.1 & 7.4 & 14.2 \\
\hline Mean & 21.7 & 18.5 & 18.6 & 16.0 & 11.4 & 16.5 \\
\hline
\end{tabular}


Table.3 Accumulated Heliothermal Unit $\left({ }^{\circ} \mathrm{Chr}\right)$ in different phenological stages of Luit and TTB-404 under four different sowing dates during kharif, 2015

\begin{tabular}{|c|c|c|c|c|c|c|}
\hline $\begin{array}{c}\text { Date } \\
\text { Of } \\
\text { Sowing }\end{array}$ & $\begin{array}{l}\text { Sowing to } \\
\text { emergence }\end{array}$ & $\begin{array}{l}\text { Emergence to } \\
\text { transplanting }\end{array}$ & $\begin{array}{c}\text { Transplanting } \\
\text { to } \\
\text { Maximum } \\
\text { Tillering } \\
\end{array}$ & \begin{tabular}{|c|} 
Maximum \\
Tillering \\
To \\
$50 \%$ flowering \\
\end{tabular} & $\begin{array}{c}50 \% \\
\text { flowering to } \\
\text { Physiological } \\
\text { Maturity }\end{array}$ & $\begin{array}{c}\text { Sowing to } \\
\text { Physiological } \\
\text { maturity }\end{array}$ \\
\hline \multicolumn{7}{|c|}{ Luit } \\
\hline $\begin{array}{l}\text { D1- 26 June, } \\
2015\end{array}$ & 495.3 & 1539.8 & 1971.2 & 1680.2 & 2547.2 & 8233.7 \\
\hline $\begin{array}{l}\text { D2- } 11 \text { July, } \\
2015\end{array}$ & 392.1 & 2081.2 & 1322.4 & 1803.0 & 2699.2 & 8297.9 \\
\hline $\begin{array}{c}\text { D3- } 26 \text { July, } \\
2015\end{array}$ & 1028.6 & 1369.9 & 647.1 & 2699.0 & 2583.2 & 8327.8 \\
\hline $\begin{array}{c}\text { D4-10 } \\
\text { August, } 2015\end{array}$ & 594.2 & 639.7 & 1412.4 & 2945.7 & 2309.5 & 7901.5 \\
\hline Mean & 627.6 & 1407.7 & 1338.3 & 2282.0 & 2534.8 & 8190.2 \\
\hline \multicolumn{7}{|c|}{ TTB -404} \\
\hline $\begin{array}{l}\text { D1- 26 June, } \\
2015\end{array}$ & 495.3 & 1539.8 & 3499.6 & 2876.9 & 2707.3 & 11118.9 \\
\hline $\begin{array}{l}\text { D2- } 11 \text { July, } \\
2015\end{array}$ & 392.1 & 2081.2 & 3065.8 & 3150.7 & 2322.1 & 11011.9 \\
\hline $\begin{array}{c}\text { D3- 26 July, } \\
2015\end{array}$ & 1028.6 & 1369.9 & 3548.7 & 2771.6 & 1924.1 & 10642.9 \\
\hline $\begin{array}{c}\text { D4-10 } \\
\text { August, } 2015\end{array}$ & 594.2 & 639.7 & 5035.6 & 2210.6 & 1037.2 & 9517.3 \\
\hline Mean & 627.6 & 1407.7 & 3787.4 & 2752.5 & 1997.7 & 10572.8 \\
\hline
\end{tabular}

Table.4 Heat Use Efficiency $\left(\mathrm{kg} / \mathrm{ha} /{ }^{\circ} \mathrm{C}\right)$ for straw and grain yield at maturity in Luit and TTB404 during kharif, 2015

\begin{tabular}{|c|c|c|c|c|}
\hline \multirow{2}{*}{$\begin{array}{c}\text { Date of } \\
\text { Sowing }\end{array}$} & \multicolumn{2}{|c|}{ Luit } & \multicolumn{2}{c|}{ TTB -404 } \\
\cline { 2 - 5 } & $\begin{array}{c}\text { HUE } \\
\text { (Straw) }\end{array}$ & $\begin{array}{c}\text { HUE } \\
\text { (Grain) }\end{array}$ & $\begin{array}{c}\text { HUE } \\
\text { (Straw) }\end{array}$ & HUE (Grain) \\
\hline D1-26 June, 2015 & 3.0 & 1.6 & 3.5 & 2.0 \\
\hline D2- 11 July, 2015 & 3.1 & 1.8 & 4.1 & 2.3 \\
\hline D3- 26 July, 2015 & 3.2 & 1.9 & 4.7 & 2.2 \\
\hline D4-10 August, 2015 & 3.2 & 1.4 & 5.2 & 2.1 \\
\hline Mean & $\mathbf{3 . 1}$ & $\mathbf{1 . 7}$ & $\mathbf{4 . 4}$ & $\mathbf{2 . 2}$ \\
\hline
\end{tabular}


Table.5a Accumulated thermal indices at different phenophases and grain yield of Luit and TTB-404 during kharif, 2015

\begin{tabular}{|c|c|c|c|c|c|c|c|c|c|c|c|c|c|}
\hline \multirow[t]{2}{*}{ Cultivar } & \multirow{2}{*}{$\begin{array}{l}\text { Date of } \\
\text { sowing }\end{array}$} & \multirow[b]{2}{*}{ 可 } & \multicolumn{3}{|c|}{ GDD } & \multicolumn{3}{|c|}{ HTU } & \multicolumn{3}{|c|}{ PTI } & \multicolumn{2}{|c|}{ HUE } \\
\hline & & & $\sum_{1}^{E}$ & 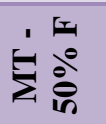 & $\sum_{0}^{1}$ & $\sum_{\substack{1 \\
1 \\
1}}$ & 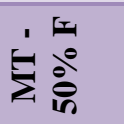 & $\frac{1}{2} \sum_{i}^{0}$ & $\sum_{1}^{E}$ & 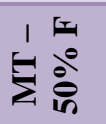 & 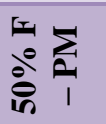 & 离 & कृ \\
\hline \multirow[t]{4}{*}{ Luit } & D1 & 3160 & 358.1 & 564.7 & 507.3 & 1971.2 & 1680.2 & 2547.2 & 18.8 & 18.2 & 18.8 & 1.6 & 3.0 \\
\hline & D2 & 3263 & 350.7 & 552.9 & 467.1 & 1322.4 & 1803.0 & 2699.2 & 18.5 & 18.4 & 17.3 & 1.8 & 3.1 \\
\hline & D3 & 3240 & 317.3 & 544.8 & 404.2 & 647.1 & 2699.0 & 2583.2 & 17.6 & 18.8 & 15.5 & 1.9 & 3.2 \\
\hline & D4 & 2386 & 321.4 & 520.6 & 387.7 & 1412.4 & 2945.7 & 2309.5 & 18.9 & 17.4 & 12.9 & 1.4 & 3.2 \\
\hline \multirow[t]{4}{*}{ TTB-404 } & D1 & 4989 & 922.8 & 597.8 & 452.3 & 3499.6 & 2876.9 & 2707.3 & 19.2 & 19.3 & 15.1 & 2.0 & 3.5 \\
\hline & D2 & 5354 & 903.6 & 564.4 & 390.2 & 3065.8 & 3150.7 & 2322.1 & 18.8 & 17.6 & 12.6 & 2.3 & 4.1 \\
\hline & D3 & 4842 & 934.1 & 452.3 & 316.5 & 3548.7 & 2771.6 & 1924.1 & 18.7 & 15.1 & 10.6 & 2.2 & 4.7 \\
\hline & D4 & 4298 & 958.9 & 374.6 & 245.1 & 5035.6 & 2210.6 & 1037.2 & 17.8 & 12.1 & 7.4 & 2.1 & 5.2 \\
\hline \multirow[t]{3}{*}{ Overall } & Mean & 3941.5 & 633.4 & 521.5 & 396.3 & 2562.9 & 2517.2 & 2266.2 & 18.5 & 17.1 & 13.8 & 1.9 & 3.8 \\
\hline & SD & 1069.9 & 317.6 & 73.1 & 84.4 & 1468.7 & 549.9 & 559.8 & 0.6 & 2.4 & 3.7 & 0.3 & 0.8 \\
\hline & $\mathrm{CV}(\%)$ & 27.1 & 50.1 & 14.0 & 21.3 & 57.3 & 21.8 & 24.7 & 3.0 & 14.0 & 26.8 & 15.9 & 22.0 \\
\hline
\end{tabular}

(Where, $\mathrm{T}=$ Transplanting, MT= Maximum tillering, $50 \% \mathrm{~F}=50 \%$ flowering, $\mathrm{PM}=$ Physiological maturity)

Table.5b Correlation coefficient of grain yield (kg/ha) of Luit and TTB-404 with different thermal indices

\begin{tabular}{|c|c|c|c|c|c|c|c|c|c|c|c|c|}
\hline & Yield & $\begin{array}{c}T-M T \\
(G D D)\end{array}$ & $\begin{array}{c}M T- \\
50 \% F \\
(G D D)\end{array}$ & $\begin{array}{c}50 \% \mathrm{~F}- \\
P M \\
(G D D)\end{array}$ & $\begin{array}{c}T-P M \\
(H T U)\end{array}$ & $\begin{array}{c}M T- \\
50 \% F \\
(H T U)\end{array}$ & $\begin{array}{c}50 \% F- \\
P M \\
(H T U)\end{array}$ & $\begin{array}{c}T-M T \\
(P T I)\end{array}$ & $\begin{array}{c}M T- \\
50 \% F \\
(P T I)\end{array}$ & $\begin{array}{c}50 \% \mathrm{~F}- \\
P M \\
(P T I)\end{array}$ & $\begin{array}{c}\text { Grain } \\
(\text { HUE })\end{array}$ & $\begin{array}{c}\text { Straw } \\
(\boldsymbol{H U E})\end{array}$ \\
\hline Yield & 1.00 & & & & & & & & & & & \\
\hline T - MT (GDD) & $0.92 * *$ & 1.00 & & & & & & & & & & \\
\hline MT - 50\% F (GDD) & -0.08 & -0.39 & 1.00 & & & & & & & & & \\
\hline $50 \%$ F- PM (GDD) & -0.32 & -0.58 & $0.90 * *$ & 1.00 & & & & & & & & \\
\hline T - MT (HTU) & $0.72 *$ & $0.91 * *$ & -0.59 & -0.65 & 1.00 & & & & & & & \\
\hline MT - 50\% F (HTU) & 0.42 & 0.40 & 0.10 & -0.32 & 0.12 & 1.00 & & & & & & \\
\hline $50 \%$ F- PM (HTU) & -0.24 & -0.54 & $0.95 * *$ & $0.91 * *$ & $-0.75 *$ & 0.01 & 1.00 & & & & & \\
\hline T - MT (PTI) & 0.21 & 0.16 & 0.52 & 0.46 & 0.06 & 0.22 & 0.43 & 1.00 & & & & \\
\hline MT - 50\% F (PTI) & -0.22 & -0.52 & $0.97 * *$ & $0.89 * *$ & $-0.73 *$ & 0.08 & $0.99 * *$ & 0.40 & 1.00 & & & \\
\hline $50 \%$ F - PM (PTI) & -0.42 & -0.68 & 0.83* & $0.98 * *$ & $-0.74 *$ & -0.42 & $0.89 * *$ & 0.28 & $0.86 * *$ & 1.00 & & \\
\hline Grain (HUE) & $0.92 * *$ & $0.83 *$ & -0.26 & -0.48 & 0.63 & 0.35 & -0.36 & -0.16 & -0.35 & -0.51 & 1.00 & \\
\hline Straw (HUE) & 0.63 & $0.82 *$ & $-0.82 *$ & $-0.90 * *$ & $0.87 * *$ & 0.22 & $-0.89 * *$ & -0.26 & $-0.89 * *$ & $-0.92 * *$ & $0.71 *$ & 1.00 \\
\hline
\end{tabular}

(* Significant at 0.05 level, ** Significant at 0.01 level) 
Thus it is evident that, earlier transplanted crop availed higher degree-days and with each delay in transplanting the degree-day consumption decreased. Crop Decreased in accumulation of heat units with delay in transplanting were also recorded by Praveen et al., (2013).

\section{Phenothermal Index (PTI)}

The phenothermal index for consecutive phenophases of two rice cultivars sown during four different dates is presented in Table 2. The PTI was estimated highest in both the cultivars during the sowing to emergence i.e. 19.3 to $24.3^{\circ} \mathrm{C} /$ day which is due to lowest number of days taken to emergence. With the advancement in crop phenophases, the PTI decreases slowly and attains minimum during $50 \%$ flowering to physiological maturity stage.

The overall PTI from sowing to physiological maturity was recorded maximum in D1 followed by D2, D3 and D4 in both the cultivars. The results are in conformity with the earlier findings of Bhat et al., (2015) and Shamim et al., (2013) who reported that highest PTI in rice cultivars sown on different dates was observed during the pre-flowering stage, while it decreased gradually and became minimum at maturity stage.

\section{Heliothermal Unit (HTU)}

The HTU accumulated by rice cultivars sown and transplanted on different dates are shown in Table 3. In cv. Luit, the heliothermal units available for the crop from its sowing to physiological maturity were higher for the crop sown during D3 $\left(8327.8^{\circ} \mathrm{Chr}\right)$ followed by D2 $\left(8297.9^{\circ} \mathrm{Chr}\right), \mathrm{D} 1\left(8233.7^{\circ} \mathrm{Chr}\right)$ and D4 (7901.5 Chr). In case of Luit, the third and fourth date of transplanting exposed to more sunshine duration comparatively to first and second date of transplanting during their growth period in main crop field (Fig. 2). The total sunshine hours recorded during sowing to physiological maturity of $\mathrm{cv}$. Luit were 431.4hr, 451.9hr, 472.7hr and 492.6hr for D1, D2, D3 and D4, respectively. Similarly, during sowing to physiological maturity stage the $c v$. TTB-404 was exposed to a total sunshine hour of $622.3 \mathrm{hr}$ (D1), 666.3hr (D2), 688.5hr (D3) and 701.6hr (D4). From the above findings, it can be enumerated that with the delay in sowing the crop gets exposed to brighter sunshine hour as observed in both the cultivar. The differential behaviour of rice cultivars to heat unit requirements and HTU could be ascribed to their genetic makeup.

\section{Heat use efficiency (HUE)}

The values in Table 4 revealed that the HUE for production of grain yield in Luitranges from 1.4 to $1.9 \mathrm{~kg} / \mathrm{ha} /{ }^{\circ} \mathrm{C}$ and similarly 2.0 to $2.3 \mathrm{~kg} / \mathrm{ha} /{ }^{\circ} \mathrm{C}$ for TTB-404 (Table 4). Among different dates of sowing/ transplanting higher HUE was recorded in D2 $\left(2.3 \mathrm{~kg} / \mathrm{ha} /{ }^{\circ} \mathrm{C}\right)$ in TTB-404 whereasit was D3 $\left(1.9 \mathrm{~kg} / \mathrm{ha} /{ }^{\circ} \mathrm{C}\right)$ in case of Luit. In case of $c v$. Luit, the HUE for both straw and grain increased as sowing was delayed from 26 June (D1) to 26 July (D3) and then it decreased with further delay in sowing. However, the highest HUE for grain yield in TTB-404 was recorded in the crop sown on D2 and D3 and it was decreased in either side as the sowing was advanced or delayed. In Luit, higher HUE for both grain and straw in the crop sown on D3 (26 July) was probably due to either higher yield of straw and grain as compared to the crop sown on D4 (10 August) or lesser accumulation of GDD as compared to the crop sown on earlier dates i.e. D1 and D2. Comparatively lower HUE for grain and straw in the crop sown on D1 was recorded in TTB-404, which was due to higher accumulation of heat units by the crop. Reduction of HUE for grain in TTB-404 under delayed sown condition (D4) was due to lower biomass partitioning towards grain as 
well as lower heat unit accumulation with delay in sowing.

\section{Correlation coefficient}

The accumulated thermal indices in different phenological stages along with HUE of two rice cultivars Luit and TTB-404 sown on four different dates during kharif, 2015 were computed and correlated with grain yield (Table 5a). Correlation studies between grain yield and thermal indices showed that grain yield of both the cultivars were significantly and positively correlated with accumulated GDD and HTU from transplanting to maximum tillering stage with correlation coefficients (r) $0.92 * *$ and $0.72 *$ respectively and with grain HUE with $r$ value $0.92 * *$ (Table $5 \mathrm{~b}$ ). No significant associations of grain yield were observed with PTI accumulated at different crop growth stages.

From the above findings it can be concluded that fluctuation in the daily weather parameters influences the growth and development characteristics of rice to a great extent. It is evident from the above result that early sowing of rice cultivar yields more as compared to late sowing. It can also be concluded that yield in rice cultivars viz., Luit and TTB-404 declines if transplanted beyond the first fortnight of August. The study on thermal indices provides a clear picture on amount of heat energy as well sunshine hour consumption at different phenological stages of the $c v$. Luit and TTB-404. These information can also be used for forecasting the occurrence of different phenophases of the rice crop.

\section{References}

Abeysiriwardena, D.S., Jayanwardena, S.N., Kiriwaththuuduwage, K.D.S. and Abeysekara, S.W. (2005). Potential of broadcasting seedlings for making savings in seed, water and labour in irrigated rice production systems in Sri Lanka. In: NATIONAL RICE PROGRAMMES, 2005. International Rice Research Institute. Pp 79-82.

Abhilash, Dagar, C. S., Singh, R., Premdeep and Sharma, R. (2017). Agrometeorological Indices and Phenology of Basmati Rice (Oryza sativa L.) under Different Dates of Transplanting. Int. J. Curr. Microbiol. App. Sci. 6(3): 212-222.

Alvarado, J.R. (2002). Influence of air temperature on rice population, length of period from sowing to flowering and spikelet sterility. In: Proceedings of the second temperate rice conference. IRRI, Philippines.

Bhatt, T.A., Ahmed, L. and Kotru, R. (2015). Relation between Agrometeorological indices, crop phenology and yield of rice genotypes as influenced by real time N management. J. Agrometeorol., 17(1): 90-97.

Bierhuizen, J. F. (1973). The effect of temperature on plant growth, development and yield.In "Plant response to climatic factors".Proc. Uppsala Symp (Paris). pp. 89-98.

Chakravarty, N.V.K. and Sastry, P.S.N. (1983). Phenology and accumulated heat unit relationship in wheat under different planting dates in the Delhi region. Agril. Sci. Progress, 1: 32-42.

Chaudhari, N.V., Kumar, N., Parmar, P.K., Dakhore, K.K., Chaudhari, S.N. and Chandrawanshi, S.K. (2019).Thermal indices in relation to crop phenology and yield of rice (Oryza sativa L.) grown in the south Gujarat region. $J$. Pharmacogn. Phytochem., 8(2): 146149.

De Datta, S. K. (1981). Principles and practices of rice Production.New York, Wiley-Interscience Publications.

Gouri, V., Reddy, D.R., Rao, S.B.S.N. and 
Rao, A.Y. (2005). Thermal requirement of rabi groundnut in southern Telangana zone of Andhra Pradesh. $J$. Agrometeorol., 7(1): 90-94.

Kar, G. (1996). Effect of environmental factors on plant growth and aphid incidence in Brassica sp. and modeling crop growth. Ph.D. Thesis, IARI, New Delhi.

Kaur, A. and Dhaliwal, L. K. (2014).Agroclimatic indices of Rice (Oryza sativa L.) under different dates of planting. Progressive Research, 9(1): 222-227.

Kumar, N., Kumar, S., Nain, A.S. and Roy, S. (2014). Thermal indices in relation to crop phenology of wheat (Triticum aestivum L.) and urd (Vignamungo L. Hepper) at Tarai region of Uttarakhand. Mausam. 65(2): 215-218.

Kumar, V. and J.K. Ladha (2011). Direct seeding of rice: recent developments and future needs. Adv. Agron. 111: 297413.

Matloob, A., Khaliq, A., Tanveer, A., Rasul, F. and Wahid, A. (2015). Thermal time accumulation and heat use efficiency of direct seeded fine aromatic rice. $J$. Anim. Plant Sci., 25(3): 755-762.

Mavi, H. S. (1994). Climatic Normals for Crop and Livestock Production.In: "Introduction to Agrometeorology". Second edition. pp: 126-147.

Morris, M. (1980).Rice production. Peace Crops Information collection and exchange. Freetwon, Sierralione. 79 p.

Mote, B. M., Kumar, N. and Ban, Y. G. (2015). Thermal requirements for attainment of Phenophases of rice cultivars under variable weather conditions. Plant Archives, 15(2): 987990.

Patel and Charugamba (1981).Potential for improving rice production in Tabo Region, Tanzania and its implications for village planning. Overseas
Development of Natural Resources Institute, Arusha, Tanzania.

Praveen, K.V., Patel, S.R., Choudhary, J.L. and Bhelawe, S. (2013). Heat unit requirement of different rice varieties under Chhattisgarh plain zones of India.J. Earth Sci. Clim. Change, 5(1):1-4.

Qadir, G., Ahmad, S., Hassan, F. U. and Cheema, M. (2006). Oil and fatty acid accumulation in sunflower as influenced by temperature variations.Pak. J. Bot. 38: 1137-1147.

Rao, A.N., Jhonson, D.E., Sivaprasad, B., Ladha, J.K. and Mortimer, A.M. (2007). Weed management in direct seeded rice. Adv. Agron., 93: 153-255.

Sandhu, S. S., Kaur, P. and Gill, K. K. (2013). Weather Based Agro Indices and Grain Yield of Rice Cultivars Transplanted on Different Dates in Punjab. Internat. J. of Agri. Food Sci. Tech., 4(10): 10191026.

Shamim, M., Singh, D., Gangwar, B., Singh, K. K. and Kumar, V. (2013). Agrometeorological indices in relation to phenology, biomass accumulation and yield of rice genotypes under Western Plain zone of Uttar Pradesh. $J$. Agrometeorol, 15(Special issue- II): 5057.

Singh, A.K., Chnadra, N. and Bharti, R.C. (2012). Effects of genotype and planting time on phenology and performance of rice (Oryza sativa L.). VEG ETOS, 25: 151-156.

Singh, S. (2000).Growth, yield and biochemical response of rice cultivars to low light and high temperaturehumidity stress.Oryza37: 35-38.

Singh, S. and Pal, M. (2003). Growth, yield and phonological response of wheat cultivars to delayed sowing. Indian J. Pl. Physiol., 8:277-286.

Swaminathan, M.S. (1999). Rice in 2000 AD. In: Rice- in a variable climate. Ed: Y.P. 
Abrol and Sulochana Gadgil. APC Publications Pvt. Ltd., Post Box No. 2679, New Delhi- 110005, India. 217238.
Thomas, J. E. (1957). Climate and Agriculture, Plant Agriculture. Readings from Scientific American. W. H. Freeman and Company: 108-118.

\section{How to cite this article:}

Kuldip Medhi, Prasanta Neog, Bondita Goswami, Rajib Lochan Deka and Rofiul Hussain. 2019. Agrometeorological Indices in Relation to Phenology and Yield of Rice Genotype (Oryza sativa L.) under Upper Brahmaputra Valley Zone of Assam, India. Int.J.Curr.Microbiol.App.Sci. 8(06): 1459-1471. doi: https://doi.org/10.20546/ijcmas.2019.806.177 